\title{
Covid-19 Sürecinde Eğitime Devam Eden Öğrencilerin Sınav Kaygısı ve Psikolojik Sağlamlıklarının Karma Metodoloji ile İncelenmesi
}

\author{
DOI: 10.26466/opus.936008
}

$*$

\author{
İsmail Erol ${ }^{*}$ - Özge Erduran Tekin ** \\ * Öğr. Görevlisi Dr., Tekirdağ Namık Kemal Üniversitesi, Tekirdağ/Türkiye \\ E-Posta: ismailerol@nku.edu.tr \\ ORCID: $\quad \underline{0000-0001-8531-6001}$ \\ ** Öğr. Görevlisi, Milli Savunma Üniversitesi, Hava Harp Okulu, İstanbul/Türkiye \\ E-Posta: oerduran@hho.msu.edu.tr \\ ORCID: $\quad \underline{0000-0002-4052-1914}$
}

\section{Öz}

Bu çalışmada, pandemi sürecinde online eğitim gören on ikinci sımı öğrencilerinin sınav kaygısı ve psikolojik sağlamliklarının çeşitli değişkenler ve katılımcı görüşleri açısından incelenmesi amaçlanmıştır. Araştırmanın örneklemini, uygun örnekleme yöntemi kullanılarak seçilmiş olan 401 lise öğrencisi oluşturmuştur. Araştırmada Westside Sınav Kaygısı Ölçeği, Çocuk ve Gençler için Psikolojik Sağlamlık Ölçeği, Kişisel Bilgi Formu ve Yarı Yapılandırılmış Görüşme Formu veri toplama aracı olarak kullanılmıştır. Araştırmadan elde edilen bulgular sonucunda kız öğrencilerin online eğitim sürecine devam ederken yaşadıkları sınav kaygısının erkek öğrencilere göre daha yüksek olduğu ama psikolojik sağlamlıklarının cinsiyet değiş̧kenine göre anlaml farklılı göstermediği görülmüştür. Sinav kaygısı puanlarının okul türü değişkenine göre istatistiksel olarak anlaml derecede farklılaşmadığ ama psikolojik sağlamlık puanlarının anlaml farklılık gösterdiği görülmüş̧ür. Öğrencilerin sınav kaygısını başaramama korkusu ve heyecan olarak adlandırdıklarl; Covid-19 sürecinde kayginın arttığı ve sinavlara konsantre olamadıklarl; psikolojik sağlamlık kavramını ise güçlü olma, mutlu olma ve sağlam olma olarak nitelendirdikleri; psikolojik sağlamlıklarını korumak için spor yaptıkları, müzik dinledikleri ve aileleri ile vakit geçirdiklerini ayn zamanda sosyal medyayı kullanmaktan uzak durmaya gayret ettikleri bulgularına ulaşılmıştır.

Anahtar Kelimeler: Eğitim Bilimleri, Covid-19, Online Eğitim, Stnav Kaygısı, Psikolojik Sağlamlık. 


\title{
Examination of Exam Anxiety and Psychological Resilience of Students Continuing Education in Covid-19 Process with Mixed Methodology
}

*

\begin{abstract}
In this study, it is aimed to examine the test anxiety and psychological resilience of twelfth grade students who receive online education during the pandemic process in terms of various variables and participant views. The sample of the study consisted of 401 high school students who were selected using the appropriate sampling method. In the study, Westside Exam Anxiety Scale, Psychological Resilience Scale for Children and Youth, Personal Information Form and Semi-Structured Interview Form were used as data collection tools. As a result of the findings obtained from the study, it was observed that the exam anxiety experienced by female students while continuing their online education process was higher than that of male students, but their psychological resilience did not differ significantly according to the gender variable. It was observed that test anxiety scores did not differ significantly according to the school type variable, but psychological resilience scores showed a significant difference. What students call test anxiety, fear of failure and excitement during the Covid-19 process; anxiety increased and they could not concentrate on exams; what they describe as psychological resilience as being strong, being happy and being solid It has been found that they do sports, listen to music and spend time with their families in order to maintain their psychological resilience, and also try to stay away from using social media.
\end{abstract}

Keywords: Educational Sciences, Covid-19, Online Education, Exam Anxiety, Psychological Resilience. 


\section{Giriş}

Dünyayı etkisi altına alan Covid-19 salgını herkes için endişe verici bir durum olup (Dünya Sağlık Örgütü, 2020) pek çok insanın fiziksel ve psikolojik sağlığını olumsuz yönde etkilemiştir (Al-Rabiaah vd., 2020 ; Duan ve Zhu, 2020). Bunun yanı sıra Covid-19 küresel salgını pek çok alanda rutin hayatın aksamasına neden olmuş olup, aksamaya neden olduğu en temel alanlarda biri de eğitimdir. Bu süreçte diğer kademelerde olduğu gibi lise öğrencileri de eğitimlerine online olarak devam etmek zorunda kalmıştır. Online eğitime devam eden ve bu süreçte evde kapalı kalmak zorunda kalan öğrencilerde, online eğitimin getirdiği aksaklıkların yanı sıra; öfke, korku, kaygı, üzüntü, sosyal destek eksikliği ve çeşitli stres bozuklukları başta olmak üzere pek çok psikolojik rahatsızlık yaşandığı görülmüştür (AlAzzam vd., 2020; Brooks vd., 2020; Cao vd., 2020; Chen vd., 2020; Guessoum vd., 2020; Liu vd., 2020; Talidong ve Toquero, 2020 ).

Ergenler kimlik edinimlerinin devam ettiği kritik bir geçiş döneminde olup, yetişkinlerden farklı olarak zorlu durumları yönetebilecek psikolojik olgunluğa çoğunlukla ulaşmamıştır; bu yüzden de ergenlerin pandemi gibi küresel bir tehdit olan, yoğun ve uzun süreli tedbirler alınmasını mecbur kılan zorlu dönemlerde ruh sağlıklarını korumaları ve uzun süreli tedbirlere uymaları yetişkinlere göre çok daha zor olmaktadır (Fegert vd., 2020; Xiang vd., 2020; Crone ve Dahl, 2012; Roy vd., 2020).

Covid-19 salgını yöneticileri salgını kontrol altına alabilmek ve halkın sağlığını koruyabilmek adına sokağa çıkma yasağı uygulamaları getirmek zorunda bırakmıştır. Bu durumun çeşitli psikolojik yansımaları olmuş ve başta üniversite sınavı gibi hayatlarını belirleyecek bir sınava hazırlanan lise son sınıf öğrencilerinin kaygılarının çok daha fazla artmasına neden olmuştur (Abuhammad vd., 2020; Kim, 2020). Lise öğrencileriyle yapılan bir çalışmada online eğitime devam etmenin öğrencilerin stres seviyesini çok daha fazla artırdığı ve onları psikolojik olarak savunmasız hale getirdiği görülmektedir (Cao vd., 2020). Psikolojik olarak giderek savunmasız halen gelen, yaşanan pek çok aksaklığa rağmen online eğitime devam eden ve evde kalma süreleri tahminlerden daha fazla uzayan ergenlerin içinde bulunduğu bu durum, ergenlerin akademik 
zorluklar yaşamasına ve kaygı türlerinden biri olan sınav kaygılarının artmasina neden olmuştur (Alfoukha vd., 2019; Liang vd., 2020).

Genel olarak bakıldığında ise sınav kaygısı, tüm eğitim seviyelerindeki insanlar için ortak bir sorundur (Gibson, 2014). Bu süreçte duygusal olarak bir geçiş döneminde olan ergenler için sınav kaygısının artması kaçınılmaz olup, çalışmanın en temel amaçlarından biri Covid-19 salgını sürecinde İstanbul ilinde eğitimlerini online olarak sürdüren lise son sinıf öğrencilerindeki sınav kaygılarını çeşitli değişkenler açısından ve kendi görüşleri açısından incelemek, içinde bulunulan duruma dair bir tespitte bulunmak ve sınav kaygısının öğrencilerin akademik performansını olumsuz yönde etkilemesini önlemek adına (Brooks vd., 2015) çözüme yönelik adımlar atılmasına katkıda bulunabilmektir.

Covid-19 gibi ciddi travmatik durumlara yol açan stres kaynaklarıyla baş etmenin en önemli yollarından biri kişinin yüksek bir psikolojik dayanaklılığa sahip olması olup (Bahmani vd., 2016; Norris vd., 2009) aynı zamanda yaşanan bu durumun olumsuz etkilerini azaltmada psikolojik dayanıklılı̆̆ı bir güç kaynağı olarak kullanabilmesidir (Bahmani vd., 2016; Bethell vd., 2014; Sheerin vd., 2018). Literatür incelendiğinde psikolojik dayanaklılık öğrenilebilen ve geliştirilebilen bir kavram olup (Buz ve Genç, 2019; Luthar vd., 2000), Covid-19 sürecinde eğitimlerine online olarak devam eden lise öğrencilerinin psikolojik sağlamlıklarının tespit edilmesi ve ihtiyaç halinde geliştirilmesinin (Joyce vd., 2018) öğrencilerin bu süreçlerle baş etmesini sağlayacağı ve kaygılarının azalmasını olumlu yönde etkileyeceği ve hatta akademik başarılarını da artırabileceği düşünülmektedir (Robertson vd., 2015). Bu amaçla Covid-19 salgının başlamasıyla beraber İstanbul ilinin çeşitli ilçelerinde eğitime online olarak devam etmek zorunda olan lise son sınıftaki öğrencilerin sınav kaygısı ve psikolojik sağlamlıklarının açımlayıcı sıralı karma desen yöntemi ile derinlemesine incelenebilmesi çalışmada temel amaç olarak belirlenmiştir. Bu amaç doğrultusunda belirlenen alt amaçlar şunlardır:

1. Covid-19 sürecinde online eğitim gören on ikinci sinıf öğrencilerinin sınav kaygıları ve psikolojik sağlamlıkları ne düzeydedir? 
2. Covid-19 sürecinde online eğitim gören on ikinci sinıf öğrencilerinin sınav kaygıları cinsiyet değişkenine göre farklılaşmakta mıdır?

3. Covid-19 sürecinde online eğitim gören on ikinci sinıf öğrencilerinin sınav kaygıları okul türü değişkenine göre farklılaşmakta mıdır?

4. Covid-19 sürecinde online eğitim gören on ikinci sinıf öğrencilerinin psikolojik sağlamlıkları cinsiyet değişkenine göre farklılaşmakta mıdır?

5. Covid-19 sürecinde online eğitim gören on ikinci sinıf öğrencilerinin psikolojik sağlamlıkları okul türü değişkenine göre farklılaşmakta mıdır?

6. Covid-19 sürecinde online eğitim gören on ikinci sinıf öğrencilerinin sınav kaygılarını ve psikolojik sağlamlıklarını nasıl değerlendirmektedir?

Alan yazın incelendiğinde Türkiye'de bu içerikte bir araştırma yapılmadığ1 görülmekte ve araştırma sonuçlarının literatüre önemli katkılar sağlayacağ 1 düşünülmektedir. Elde edilen nicel sonuçlarla Covid19 sürecinde online eğitime devam eden on ikinci sınıf öğrencilerinin sınav süreçlerinde yaşadıkları kaygının ve psikolojik sağlamlıklarının mevcut durumuna çeşitli değişkenler açısından 1şık tutacak olup, nitel analizler kapsamında yapılan görüşmelerle elde edilen veriler ise online eğitim döneminde sinav kaygısının azaltılması ve psikolojik sağlamlıklarının artırılması amacıyla gerekli tedbirlerin alınması yönünde diğer araştırmacılara ve uygulamacılara fikir verebilecektir.

\section{Yöntem}

Araştırmanın amacı Covid-19 salgının başlamasıyla beraber eğitime online olarak devam etmek zorunda kalan lise son sınıf öğrencilerinin sınav kaygısı ve psikolojik sağlamlıklarının ne düzeyde olduğunu, cinsiyet ve okul türü değişkenine göre nasıl farklılaştığını ve öğrencilerin görüşlerini açımlayıcı sıralı karma desen yöntemi ile incelemektir. 


\section{Evren ve Örneklem}

Araştırmanın evrenini Türkiye'deki 12. sınıf öğrencileri oluştururken örneklemini, 2021 eğitim öğretim yılında eğitime online olarak devam eden ve seçkisiz olmayan örnekleme yöntemlerinden birisi olan uygun örnekleme yöntemi ile seçilen 401 öğrenci oluşturmuştur. Uygun örnekleme yönteminde, iş gücü ve zaman açısından var olan sinırlılıklar sebebi ile örneklem kolay ulaşılan ve uygulama yapılabilen birimlerden seçilir (Büyüköztürk vd., 2014). Öğrencilerin demografik özelliklerine ait olan bilgiler Tablo 2'de sunulmuştur. Çalışmadaki nitel boyutta çalışmanın nicel boyutuna katılım sağlayan öğrencilerden amaçlı örneklem seçme yönteminde bulunan maksimum çeşitlilik örneklem seçme yöntemi ile 16 katılımcı belirlenmiştir. Burada belirlenen özellik derinlemesine bilgi edinebilmek amaciyla okul türü, cinsiyet, sinav kaygısının yüksek veya düşük olması ve psikolojik sağlamlığının yüksek veya düşük olmasıdır.

Tablo 2. Öğrencilerin Demografik_Özelliklerine İlişkin Bilgiler

\begin{tabular}{llr}
\hline Değişken & N & $\%$ \\
\hline Cinsiyet & 226 & 56 \\
Erkek & 175 & 44 \\
Kız & & \\
\hline Okul & 172 & 43 \\
Anadolu Lisesi & 111 & 28 \\
Fen Lisesi & 118 & 29 \\
Meslek Lisesi & 401 & 100 \\
Toplam & &
\end{tabular}

Araştırma örneklemi \%56'sı (N=226) erkek, \%44'ü (N=175) kız olmak üzere toplam 401 öğrenciden oluşmaktadır. Öğrencilerin \%43'ü (N=172) Anadolu Lisesi'ne, \%28'i (N=111) Fen Lisesi'ne, \%29' u (N=118) Meslek Lisesi'ne devam etmektedir. Öğrenciler 12. sınıfta öğrenim görmektedir.

\section{Araştırmada Kullanılan Veri Toplama Araçları}

Araştırmada Westside Sınav Kaygısı Ölçeği, Çocuk ve Gençler için Psikolojik Sağlamlık Ölçeği, Kişisel Bilgi Formu ve Yarı Yapılandırılmış Görüşme Formu kullanılmıştır. 
Westside Sınav Kaygısı Ölçeği: Türkçe'ye uyarlaması Totan ve Yavuz (2009) tarafından yapılan ölçek orijinalinde tek bir boyut ve on maddeden oluşan ölçek Türkçe anlamayı daha kolaylaştıracağı düşünülerek on bir madde şeklinde çevrilmiştir. Ölçeğin Türkçe' ye uyarlanmasında yapılan doğrulayıcı faktör analizinde ölçeğe ait tek faktörlü yapının doğrulandığ 1 ve faktör yüklerinin .32 ile .78 arasında değiştiği görülmüştür. Totan (2018) yılında Westside Sınav Kaygısı Ölçeğinin güvenirlik ve geçerlik çalışmasını lise ve ortaokul öğrencileri için yapmış, doğrulayıcı faktör analizi sonucunda elde edilen sonuçlar ölçeğe ait hipotez modelin ortaokul ve lisede doğrulandığı, aracın geçerli ve güvenilir olduğu görülmüştür. Sınav kaygısı ölçeğinden bu çalışma için elde edilen Cronbach alfa güvenirlik katsayısı ise .87 olarak hesaplanmıştır.

Çocuk ve Gençler Için Kısa Psikolojik Sağlamlık Ölçeği: Liebenberg, Ungar ve LeBlanc (2013) tarafından kısaltılmış forma dönüştürülen ölçekten, faktör yükleri .39 ile .88 arasında değişen ve iç tutarlılık katsayısı .84 olan 12 maddelik bir yapı elde edilmiştir. Beşli likert yapıda olan ölçme aracından alınan yüksek puan yüksek sağlamlık düzeyini belirtmektedir. Arslan (2015) tarafından Türkçe' ye ortaokul ve lise öğrencilerinden oluşan örneklemde kullanılarak uyarlanmış olup, ölçeğin tek faktörlü yapısının doğrulandığı ve Cronbach alpha değerinin .91 olduğu görülmüştür. Psikolojik sağlamlık ölçeğinin bu çalışma için elde edilen Cronbach alfa güvenirlik katsayısı .81 olarak hesaplanmıştır.

Kişisel Bilgi Formu : Araştırmacılar tarafından oluşturulan kişisel bilgi formu yardımıyla, katılımcılardan öğrenim sürdürdükleri okul türü ve cinsiyet durumuna ilişkin bilgiler toplanmıştır. Hem nicel hem de nitel veri toplama aşamasında kişisel bilgi formundan yararlanılmıştır.

Yarı Yapılandırılmış Görüşme Formu: Araştırmanın nitel boyutunda ise araştırmacılar tarafından oluşturulan yarı yapılandırılmış görüşme formları kullanılmıştır. Bu formlar, nicel verilerin analizi ile elde edilen bulgular ve alanyazın araştırılarak hazırlanmıştır. Formları uzman iki öğretim üyesinin incelemesinden sonar soruların anlaşılırlığı üzerine bir öğrenciye pilot uygulama gerçekleştirilmiş, gerekli düzeltmeler sonrasında nihai hali verilmiştir. Nitel araştırmalarda geçerliği 
sağlamanın en temel yollarından biri elde edilen kategori ve yorumların doğruluğu ve ayrıntılı şekilde raporlanmasıyken, güvenirlik farklı uzmanlar tarafından verilerin yorumlanmasındaki farkı en aza bindirebilmektir (Büyüköztürk vd., 2014; Yıldırım ve Şimşek, 2019). Bu sebeple verilerin yorumlanması sürecinde alanında uzman olan iki öğretim üyesinden görüş alınmıştır. Görüşme formundaki sorular aşağıdaki gibidir:

- Sınav kaygısı denilince ne anliyorsunuz?

- Covid-19 sürecinde eğitimlerinize online olarak devam ettiniz ve sınavlarınız online olarak yapılacak. Tüm bu süreçlerde sizce sinav kaygısı yaşıyor musunuz?

- Kaygınıza 1'den 10'a kadar puan verseniz kaç olurdu?

- Sizce sınav kaygınızı azaltmak için neler yapılabilir?

- Psikolojik sağlamlık denilince ne anlıyorsunuz?

- Covid-19 sürecinde eğitimlerinize online olarak devam ettiniz ve evdeydiniz. Tüm bu süreçlerde psikolojik sağlamlığınızı korumak için neler yaptınız?

- Psikolojik olarak sağlamlığınıza 1'den 10'a kadar puan verseniz kaç olurdu?

- Bu süreçte psikolojik sağlamlığınızı arttırmak adına sizce neler yapilabilirdi?

\section{Verilerin Toplanması}

Çalışmadaki veriler hem nicel hem de nitel boyut kapsamında ayrı ayrı elde edilmiştir. Veriler 2021 Nisan ayında toplanmıştır. Çalışma da anketlerin doldurulması ve görüşmelerin yapılması internet üzerinden gerçekleştirilmiştir. Çalışmanın nitel boyutunda yaklaşık 32-40 dakika süre ile gerçekleşen tüm görüşmeler internet aracılığ cevaplar formlar üzerine yazılmıştır.

\section{Verilerin Analizi}

Araştırmanın ilk safhasında öğrencilere ait olan demografik bilgilere ulaşmak, sınav kaygısı ve psikolojik sağlamlık seviyelerini belirleyebilmek için anket yöntemi kullanılmıştır. Araştırmanın ikinci 
safhasında ise nicel boyutta belirlenmiş olan öğrenciler ile yarı yapılandırılmış görüşmeler gerçekleştirilmiştir. Karma yöntemle nicel ve nitel yöntemlerden herhangi birisinin zayıf ya da eksik olarak görülen bir yönü, diğerinin güçlü tarafı sayesinde kapatılabilir (Creswell ve Plano Clark, 2015). Nicel araştırma yöntemi ile öğrencilerin sınav kaygısı ve psikolojik sağlamlıklarının cinsiyet ve okul türü değişkenine göre farklılaşıp farklılaşmadığı incelenirken, nitel araştırma yöntemi ile de öğrencilerin sınav kaygısı ve psikolojik sağlamlık konusundaki görüşlerinin incelenmesi hedeflenmiştir. Ölçekten gelen veriler üzerinde SPSS 22 paket programı ile çeşitli istatistiksel işlemler uygulanarak araştırmanın alt problemlerine cevap aranmıştır. Nicel verilerin normal dağılıp dağılmadığını belirleyebilmek için çarpıklık ve basıklık katsayılarına bakılmış ve katsayıların -1 ile +1 arasında kalarak normal dağılımdan önemli bir sapma göstermediği görülmüştür (Field, 2009). Verilerin normal olarak dağıldığını gösteren çarpıklık ve basıklık değerleri Tablo 1'de sunulmuştur.

Tablo 1. Çarpıklık ve Basıklık Değerleri

\begin{tabular}{llll}
\hline & $\mathbf{N}$ & Çarpıklık & Basıklık \\
\hline Sınav kaygısı toplam puan & 401 & -.070 & -.519 \\
Psikolojik sağlamlık toplam puan & 401 & -.367 & -.509 \\
\hline
\end{tabular}

Nitel verilerin analiz sürecinde ise "içerik analizi" yöntemi tercih edilmiştir. İçerik analizi ile edinilen veriler kavramsallaştırılır, anlaşılacak bir biçimde düzenlenir ve temalar oluşturulur (Yıldırım ve Şimşek, 2019). İçerik analizinde hedef, görüşmeler vasıtası ile toplanan ve birbirine benzeyen verileri belli başlı temalar altında toplamak ve bu temaları düzenli bir formata sokmaktır (Metin, 2014). Öncelikle 16 görüşme sonucunda elde edilen veriler yazı ile bilgisayar ortamına geçirilmiştir. Görüşmelerden 55 sayfa veri elde edilmiştir. 16 görüşme verisi öğrenci kodları ile (Ö1, Ö2, Ö3, Ö4, Ö5, vb.) kaydedilmiştir. Daha sonra düzenlenen bu veriler MAXQDA 2020 yazılımıla düzenli hale getirilmiştir. Analiz için veriler tekrar tekrar okunarak araştırma soruları kapsamında irdelenmiştir. Elde edilen veriler bulgular bölümünde araştırma sorularına göre sistematik bir şekilde verilmiş ve doğrudan alıntılarla desteklenmiştir. 


\section{Bulgular}

Araştırmanın bu bölümünde, sınav kaygısı yaşayan on ikinci sınıf öğrencilerinden elde edilen bulgulara yer verilmiştir. Araştırmadan elde edilen bulgular nicel ve nitel boyutlarda ayrı ayrı ele alınmıştır.

\section{Nicel Bulgular}

Araştırmada aritmetik ortalama ve standart sapma gibi betimsel analizlerin yanı sıra Anova, $\mathrm{t}$ testi analizleri ve nitel analiz kullanılmıştır.

Tablo 3. Öğrencilerin Sınav Kaygısı ve Psikolojik Sağlamlık Puanları ile İlgili Aritmetik Ortalama ve Standart Sapma Değerleri

\begin{tabular}{llllll}
\hline & N & Min. puan & Max. puan & $\overline{\mathbf{x}}$ & Ss \\
\hline Sinav Kaygisı Toplam Puan & 401 & 13 & 52 & 32.82 & 8.09 \\
Psikolojik Sağlamlik Toplam & 401 & 28 & 60 & 46.36 & 6.62 \\
Puan & & & & & \\
\hline
\end{tabular}

Öğrencilerin sınav kaygısı psikolojik sağlamlık puanlarına ilişkin bulgular Tablo 3'de görülmektedir. Tablo 3 incelendiğinde, araştırmaya katılan öğrencilerin ( $\mathrm{N}=401)$ sınav kaygısı puanlarının aritmetik ortalaması 32.82 standart sapması ise $8.09^{\prime}$ dur. Öğrencilerin ölçekten elde ettikleri toplam puanların 13 ile 52 arasında değiştiği görülmektedir. Bu haliyle de öğrencilerin sınav kaygısı ortalama puanlarının, ölçekten elde edilebilecek ortalamanın üzerinde olduğu yani öğrencilerin sınav kaygısının yüksek olduğu anlaşılmaktadır.

Yine araştırmaya katılan öğrencilerin $(\mathrm{N}=401)$ psikolojik sağlamlık puanlarınin aritmetik ortalaması 46.36 standart sapması ise 6.62 dir. Öğrencilerin ölçekten elde ettikleri toplam puanların 28 ile 60 arasında değiştiği görülmektedir. Bu haliyle de öğrencilerin psikolojik sağlamlık ortalama puanlarının, ölçekten elde edilebilecek ortalamanın üzerinde olduğu yani öğrencilerin psikolojik sağlamlıklarının beklenenden yüksek olduğu anlaşılmaktadır. 
Tablo 4. Sınav kaygısı puanlarının cinsiyet değişkenine göre farklılaşıp farklılaşmadığına ilişkin bă̆ımsız gruplar t-testi sonuçları

\begin{tabular}{lllllll}
\hline Cinsiyet & $\mathbf{N}$ & $\overline{\boldsymbol{x}}$ & Sd & $\mathbf{d f}$ & $\mathbf{t}$ & $\mathbf{P}$ \\
\hline Erkek & 226 & 31.40 & 8.09 & 399 & -4.071 & .000 \\
$\mathbf{K} \mathbf{\prime z}$ & 175 & 34.65 & 7.73 & & & \\
\hline
\end{tabular}

$p<0.01$

Tablo 4'e göre erkek ve kız lise son sınıf öğrencilerinin sınav kaygısı puan ortalamaları incelendiğinde, erkek öğrencilerin sınav kaygısı puan ortalamalarının 31.40 olduğu; kız öğrencilerin sınav kaygısı puan ortalamalarının ise 34.65 olduğu görülmüştür. Yapılan analiz sonucunda sınav kaygısı puan ortalamalarına göre kı öğrencilerin puan ortalamalarının erkek öğrencilerden istatistiksel olarak anlamlı düzeyde daha yüksek olduğu saptanmıştır $(\mathrm{p}<0.01)$. Bu sonuca kız öğrencilerin Covid 19 sürecinde online eğitim sürecine devam ederken yaşadıkları sınav kaygısının erkek öğrencilerin yaşadığı sınav kaygısına göre daha yüksek olduğunu söyleyebiliriz.

Tablo 5. Psikolojik sağlamlık puanlarının cinsiyet değişkenine göre farklılaşıp farklılaşmadığına ilişkin bağımsız gruplar t-testi sonuçları

\begin{tabular}{lllllll}
\hline Cinsiyet & $\mathbf{N}$ & $\overline{\boldsymbol{x}}$ & Sd & df & t & P \\
\hline Erkek & 226 & 46.27 & 6.89 & 399 & -.310 & .757 \\
Kiz & 175 & 46.47 & 6.27 & & \\
\hline
\end{tabular}

$p<0.01$

Tablo 5'e göre erkek ve kız lise son sınıf öğrencilerinin psikolojik sağlamlık puan ortalamaları incelendiğinde, erkek öğrencilerin psikolojik sağlamlık puan ortalamalarının 46.27 olduğu; kız öğrencilerin psikolojik sağlamlık puan ortalamalarının ise 46.47 olduğu görülmüştür. Yapılan analiz sonucunda psikolojik sağlamlık puan ortalamalarına göre kız öğrencilerin puan ortalamalarının erkek öğrencilerden istatistiksel olarak anlamlı düzeyde farklı olmadığı saptanmıştır $(\mathrm{p}<0.01)$.

Tablo 6. Sınav kaygısı puanlarının okul türü değişkenine göre farklılaşma durumu ile ilgili Anova sonuçları

\begin{tabular}{lllllll}
\hline & Varyansın Kaynağı & $\begin{array}{l}\text { Kareler } \\
\text { Toplamı }\end{array}$ & Sd & Kareler Ort. & F & p \\
\hline Okul Türü & Gruplararası & 14.553 & 2 & 7.276 & .111 & .895 \\
& Grup içi & 26182.641 & 398 & 65.786 & & \\
& Toplam & 26197.194 & 400 & & & \\
\hline
\end{tabular}


Tablo 6 incelendiğinde sınav kaygısı puanlarının okul türü (Anadolu lisesi, Fen lisesi ve Meslek lisesi) değişkenine göre istatistiksel olarak anlamlı derecede farklılaşmadığı görülmüsştür $\left[\mathrm{F}_{(2-398)}=.111, \mathrm{p}>0,05\right]$.

Tablo 7. Psikolojik sağlamlık puanlarını okul türü değişkenine göre farklılaşma durumu ile ilgili Anova sonuçlar

\begin{tabular}{llllllll}
\hline & Varyansın Kaynağı & $\begin{array}{l}\text { Kareler } \\
\text { Toplamı }\end{array}$ & Sd & Kareler Ort. & F & p & LSD \\
\hline Okul Türü & Gruplararası & 338.868 & 2 & 169.434 & 3.917 & .021 & Anadolu \\
& Grup içi & 17216.274 & 398 & 43.257 & & & Lisesi- \\
& Toplam & 17555.142 & 400 & & & & Fen \\
& & & & & & Lisesi \\
& & & & & Anadolu \\
& & & & & Lisesi- \\
& & & & & Meslek \\
& & & & & Lisesi \\
\hline
\end{tabular}

Tablo 7 incelendiğinde psikolojik sağlamlık puanlarının okul türü (Anadolu lisesi, fen lisesi ve meslek lisesi) değişkenine göre istatistiksel olarak anlamlı derecede farklılık gösterdiği görülmüştür $\left[\mathrm{F}_{(2-398)}=3.917\right.$, $\mathrm{p}<0,05]$. Varyanslar homojen ve grup sayısı $3^{\prime}$ ten büyük olmadığı için, farklılığın hangi gruplar arasından kaynaklandığını saptamak amacıyla LSD çoklu karşılaştırma testi kullanılmış ve sonucunda Anadolu lisesindeki öğrencilerin psikolojik sağlamlığı $(\overline{\boldsymbol{x}}=-1.86414)$ ile Fen lisesindeki öğrencilerin psikolojik sağlamlığı arasında anlamlı farklılık vardır ( $\mathrm{p}=.020)$. Fen lisesindeki öğrencilerin psikolojik sağlamlıkları Anadolu lisesindeki öğrencilere göre daha yüksektir. Yine Anadolu lisesindeki öğrencilerin psikolojik sağlamlığ $(\overline{\boldsymbol{x}}=-1.85101)$ ile Meslek lisesindeki öğrencilerin psikolojik sağlamlığı arasında anlamlı farklılık vardır ( $\mathrm{p}=0.19$ ). Meslek lisesindeki öğrencilerin psikolojik sağlamlıkları Anadolu lisesindeki öğrencilere göre daha yüksektir.

\section{Nitel Bulgular}

Araştırmanın bu bölümünde, görüşme yapılan öğrencilerden elde edilen bulgulara yer verilmiştir. Aşağıda Tablo 8'de, öğrenciler ile yapılan yarı yapılandırılmış görüşmelerden toplanılan verilerin soru bazlı analizleri sonucu oluşan kodlar listelenmiştir: 
Covid-19 Sürecinde Eğitime Devam Eden Öğrencilerin Sınav Kaygısı ve Psikolojik

Sağlamlıklarının Karma Metodoloji ile İncelenmesi

Tablo 8. Verilerin soru bazlı kodlanması

\begin{tabular}{|c|c|}
\hline Sorular & Kodlar \\
\hline 1. Araştırma Sorusu & $\begin{array}{l}\text { Başaramama korkusu (11), Heyecan (9), Fiziksel çöküntü (5), Ellerin Titremesi } \\
\text { (4), Başkalarının düşünceleri (3), Rakiplerle rekabet (3), Stres (2), Endişe (2), } \\
\text { Uyuyamamak (2), Aile baskısı (2), Tuvaletin gelmesi (2), Hayatın bütünü (2), } \\
\text { Emeklerin çöpe gitmesi (2), Düşük not alma (2), Sınıfta kalma (1). }\end{array}$ \\
\hline 2. Araştırma Sorusu & $\begin{array}{l}\text { Kaygının artması (8), Konsantre olamama (7), Online sistemin başarısızlığı (6), } \\
\text { Sınav uyumsuzluğu (5), Motivasyonel eksiklikler (5), Çalışma programını } \\
\text { oturtamama (3), Yakınları kaybetme (3), Kaygı yaşamama (3), Devamsızlık (2), } \\
\text { Sıkıcılık (2), Sağlığın önemi (2), Rahatlık (2), Not kaygısı (1), Materyal eksikliği } \\
\text { (1), Rekabet (1). }\end{array}$ \\
\hline 3. Araştırma Sorusu & Yedi (5), Sekiz (4), Altı (4), Dokuz (2), Beş (1). \\
\hline 4. Araştırma Sorusu & $\begin{array}{l}\text { Ders çalışma (8), Psikolojik testler ve destek (4), Müzik dinleme ve söyleme (4), } \\
\text { Spor yapma (4), Nefes egzersizleri (3), Kitap okuma (3), Online sınavlar (3), } \\
\text { Sokağa çıma izni (2), Rahat ortamlar (2), Sınavların kolaylaştırılması (2), Sosyal } \\
\text { medya (2), Kendine güven (1), Tedbirlerin arttırılması (1), İlgili öğretmenler (1), } \\
\text { Anne baba ilgisi (1). }\end{array}$ \\
\hline 5. Araştırma Sorusu & $\begin{array}{l}\text { Güçlü olma (12), Mutlu olma (6), Sağlam olma (6), Yılmama (4), İyi olma (3), } \\
\text { Üstesinden gelme (2), Toparlayabilme (2), Dik durma (2), Soğukkanlılık (1), } \\
\text { Takıntılı olmamak (1). }\end{array}$ \\
\hline 6. Araştırma Sorusu & $\begin{array}{l}\text { Spor yapma (9), Müzik dinleme (7), Aile ile vakit geçirme (6), Sosyal medya } \\
\text { kullanma (6), Yürüyüş (5), Kitap okuma (4), Dua etme (4), Düzenli uyku (4), Film } \\
\text { dizi izleme (4), Sağlıklı beslenme (3), Programlı çalışma (3), Şiir okuma yazma } \\
\text { (3), Video izleme (3), Dans etme (2), Sanat (2), Mutlu olma (1), Ders çalışma (1). }\end{array}$ \\
\hline 7. Araştırma Sorusu & Altı (7), Dokuz (1), Dört (2), Yedi (4), Sekiz (2). \\
\hline 8. Araştırma Sorusu & $\begin{array}{l}\text { Spor ve hareket (13), Sosyal medyayı kullanmama (9), Arkadaşlarla görüşme (7), } \\
\text { Düzenli program (5), Müzik dinleme ve söyleme (5), Dizi film izleme (5), Kitap } \\
\text { okuma (4), Sağlıklı beslenme (4), Uyku düzeni (3), Verimli çalışma (3), Aile ile } \\
\text { vakit (2), Çiçek yetiştirme (2), Evcil hayvan bakma (2), Kendine değer verme (1), } \\
\text { Hedef belirleme (1), Dua etme (1), Bilgisayar oyunu oynama (1). }\end{array}$ \\
\hline
\end{tabular}

Sınav kaygısı yaşayan 12. sınıf öğrencileri ile yapılan yarı yapılandırılmış görüşmeler aracılığı ile edinilmiş verilerin analizinden elde edilen kodlar, sekiz (8) temada bir araya getirilmiş ve Tablo 9'da sunulmuştur.

\section{Tablo 9. Temaların oluşturulması}

\begin{tabular}{ll}
\hline Tema 1 & Sınav Kaygısı ve Sonuçları \\
Tema 2 & Covid-19 Süreci Eğitim Sistemi ve Kaygılar \\
Tema 3 & Ortalamanın Üstünde Kaygı Durumu \\
Tema 4 & Covid-19 Süreci Sınav Kaygısını Azaltma Önerileri \\
Tema 5 & Psikolojik Sağlamlığın Anlamlandırılması \\
Tema 6 & Psikolojik Sağlamlığın Korunması \\
Tema 7 & Kişisel Psikolojik Sağlamlığın Derecelendirilmesi \\
Tema 8 & Covid-19 Sürecinde Psikolojik Sağlamlık Derecesini Arttırma Önerileri \\
\hline
\end{tabular}




\section{Nitel Bulguların Yorumlanması}

Sınav kaygısı yaşayan on ikinci sınıf öğrencileri ile yapılan yarı yapılandırılmış görüşmeler vasıtası ile elde edilmiş olan veriler, yukarıdaki tema başlıklarına uygun olarak şu şekilde yorumlanmıştır:

Sınav Kaygısı ve Sonuçları: Araştırmanın nitel bulgularına göre on ikinci sınıf öğrencileri; sınav kaygısı denildiği zaman "başaramama korkusunun" (11/16) kendilerinde ciddi bir baskı yarattığını; anlam olarak sınav kaygısının kendilerinde "heyecan" (9/16) uyandırdığını; sınavlarda kaygılanmanın kendilerinde "fiziksel çöküntü" (5/16) yarattığını dile getirmekle beraber aynı zamanda sinav kaygısının kendilerinde "rakiplerle rekabet" (3/16) süreci, "ellerin titremesi" (4/16); "başkaları ne der?" (3/16) düşüncelerini oluşturduğu dile getirmişlerdir. Aynı zamanda öğrenciler sinav kaygısı denildiğinde "stres" (2/16), "endişe" (2/16), "uyuyamama" (2/16), "aile baskısı" (2/16), "tuvaletin gelmesi" (2/16) gibi durumları yaşadıklarını ifade ederken; birkaç öğrenci de sınav kaygısını kendileri adına; "hayatın bütünü" (2/16), "emeklerin çöpe gitmesi" (2/16), "düşük not alma" (2/16) ve "sinıfta kalma" (1/16) olarak nitelendirmiştir. Bu tema ile ilgili öğrencilerden bazılarının görüşleri şu şekildedir:

"Sinavlara girmeden önce heyecanlanmak, belki gece uyuyamamak. Sinava girince ellerin titremesi. Benim ellerim terliyor... Santrm bu sinav kaygıs oluyor." (Ö1).

"Sinavlar için stres olmak, heyecan yapmak... Başarısız olma korkusu, hatta el alem ne der korkusu. Anneme, babama, arkadaşlara, hocalara ne derim korkusu. Benim hakkımda "tembel bu kız" derler mi korkusu..." (Ö3).

"...Karnının ağrıması, tuvaletinin gelmesi. Stres olmak yani, bu da başarım düşürüyor zaten..." (Ö4).

"Sınav kaygısı benim hayatım. Çünkü hedeflerim yüksek. Sinav kaygısı denilince de yapamam korkusu, emeğimin karşılığın almama endişesi gibi şeyleri anlıyorum... sürekli çalışıyoruz. Yoruluyoruz ve hep rekabet altındayız. Tabi ki böylesine rekabette kaygıyı doğuruyor." (Ö6).

“...Okul derslerinden kalmak da geçmek önemli tabi. Bazen yeterince çalışmadığımda daha çok olmak üzere okul derslerinden kalmak ile ilgili kaygilanıyorum." (Ö11). 
Covid-19 Süreci Eğitim Sistemi ve Kaygılar: Araştırmanın nitel bulgularına göre on ikinci sınıf öğrencilerinden bazıları bu süreçte "kaygl yaşamadıklarını" (3/16) aksine "rahat" (2/16) olduklarını ifade etse de; öğrencilerin büyük bir çoğunluğu eğitimlere online olarak devam edilmesinin kendilerinde "kaygı artışı" (8/16) durumuna yol açtı̆̆ına; derslerine ve sinavlarına "konsantre olamama" (7/16) hali yaşadıklarına; bu süreçte "online sistemin başarısızlığı" (6/16) üzerinde durulması gerektiğine; derslerin online olarak işlenmesi fakat sınavların yüz yüze yapılmasından dolayı "sinav uyumsuzluğu" (5/16) çektiklerine değinmişlerdir. Bununla beraber öğrenciler bu süreçte "motivasyonel eksiklikler" (5/16) yaşadıklarını; evde "çalışma programlarını oturtamama" (3/16) sorununa sahip olduklarını; aynı zamanda Covid-19 sürecinde "yakınları kaybetme" (3/16) stresi çektiklerini; "devamsızlık" (2/16) problemi yaşarken de derslerin "sıkıcı" (2/16) olduğunu dile getirmişler ve Covid19 sürecinde "sağlığın önemi" (2/16); üzerinde durmuşlardır. Bununla beraber; "not kaygısı" (1/16), "materyal eksikliği" (1/16) çeken ve "rekabet" (1/16) stresi yaşayan öğrenciler de bulunmaktadır. Bu tema ile ilgili öğrencilerden bazılarının görüşleri şu şekildedir:

"Online eğitim kesinlikle yüz yüze eğitim gibi başarılı değil. En azından ben motive olamıyorum. Evde kardeşim var mesela, onun da online dersleri oluyor. Bizim evde 2 bilgisayar var ama olmayan çok insan var. Ne bileyim yeterli interneti olmayan da var. Kısacası zor bir dönem ve Covid-19 süreci benim sinav kaygımı arttırdı." (Ö1).

"Bu süreç bence kesinlikle kaygıyı arttırdı. Ben online eğitime kesinlikle konsantre olamıyorum. Zaten alışana kadar çok çektim ama sürekli evde olmak da büyük sorun. Kulaklık takıyorum evet ama evdekiler hareket halindeler. Bizim ev kalabalık ve küçük, ister istemez odaya giren çıan oluyor..." (Ö3).

"Bence bu süreçte kaygı arttı. Yani online dersler çok verimli değil gibi. Katılamadı̆̆ımız zamanlar da oldu. Zaten yüz yüzeyken bile zor anladı̆̆ım şeyler var online hiç anlayamıyorum..." (Ö4).

"Online dersler iyi hoş ama yüz yüze eğitim kadar verimli olduğunu düşünmüyorum. Yani istediğimiz kadar dersleri önemseyelim ama ev ortamı sonuçta. Ne bileyim evde ses yapan olmasa bile alt ya da üst komşu ses yapıyor. Kapı çalıyor, telefon çalıyor vs. dikkatiniz çok daha kolay dağılabiliyor..." (Ö6).

"Covid-19 sürecinin kendisi kaygl yaratıyor zaten, haliyle bu da sinavlara yansıyor. Benim için çok değişen bir şey yok ama örneğin abim Fen Lisesi son 
simıfta inanılmaz kaygısı arttı. Evde ders çalışma düzeni oturtmak zor. Ses oluyor, kafan dă̆ılıyor vs. ayrıca sürekli kapalı olmak insanı kötü etkiliyor ve insanın başarısını düşürüyor." (Ö9).

"Covid-19 sürecinde kaygımız kesinlikle artt. Zaten zor olan sinavlar kafamızın dă̆ılması ile daha da zor geldi bize. Konsantre olamadığım çok zamanlar oldu. Hatta bazen online derse bile katılamadığım ama yapacak herhangi bir şey yok..." (Ö11).

“Önemli olan sağlık... Yakınlarını kaybeden çok arkadaşımız var, en azından onlara bir kolaylık sağlanmalı diye düşünüyorum. Ya da aynı şekilde bilgisayara ve internete ulaşımı ayn olmayan çok insan var. Şimdi aynı sınava girecekler. Ben bunu adaletli bulmuyorum." (Ö14).

Ortalamanın Üstünde Kaygı Durumu: Araştırmanın nitel bulgularına göre on ikinci sınıf öğrencilerinden sınav kaygıları ile ilgili 1 ile 10 arasında bir puanlama yapılması istenmiştir. Özellikle öğrencilerin 1 ile 5 arasında bir puanlama yapmadıkları; yoğun bir şekilde 5 ile 10 arasında puanlamalar yaptıkları görülmektedir. Bu durum öğrencilerin yoğun bir şekilde kayg1 yaşadıklarını göstermektedir. Öğrencilerden (5/16)'sı puanlama da sınav kaygılarının 10 üzerinden 7 olduğunu; (4/16) öğrenci 10 üzerinden 8 olduğunu; (4/16) öğrenci 10 üzerinden 6 olduğunu; (2/16) öğrenci ise 10 üzerinden 9 olduğunu belirtmiş; sadece (1/16) öğrenci 10 üzerinden 5 puanlama yapmıştır. Öğrencilerin tamamı ortalamanın üstünde bir kaygı hali içerisinde bulunmaktadırlar. Bu tema ile ilgili öğrencilerden bazılarının görüşleri şu şekildedir:

"Şu Covid-19 sürecinde kesinlikle en az 8 veririm, hatta bazen 9. Rakiplerim tüm gün ders çalışmış ve ben geri kalmışım hissi beni çok zorluyor." (Ö1).

"Önceden 6 derdim ama şuan 9 derim. Hep bir belirsizlik. Dersler, konular, okul, ilişkiler vs. Hepsi birbirine yansıyor. Bir alan etkileniyor, moraller bozuluyor, hop diğeri düşüyor. O yüzden yeterince verimli çalışamadığımı düşünüp daha da çok kaygılanıyorum ve kaygıma kesinlikle 9 puan verebilirim." (Ö3).

"8 derim. Korkuyorum çünkü. İstediğim verimi alamadım online derslerden ve başarısız olmaktan korkuyorum tabi..." (Ö4).

"7 diyebilirim. Çünkü az değil ve beni yoruyor. Ama 9 ya da 10 seviyelerinde değil. Yani kaygım yüksek evet ama zorda olsa onunla baş edebiliyorum." (Ö6). 
"5 veririm ben. Dediğim gibi kaygılı değilim. Yani orta düzeyde kaygım var. Tabi ki her şeyi boşlamış bir insan değilim ama genel olarak kaygı duymuyorum." (Ö8).

"Yani ben kendi kaygıma 6 veririm. Çünkü aşırı artmadı. Sınavlar anlamında ben rahatım." (Ö9).

"7 diyebilirim. Çok değil ama hiç yok da değil. Hayatta ve uyanık tutacak kadar bir kaygım var tabi ki." (Ö10).

"7 derim. Az değil çünkü Covid-19 süreci kaygımı daha da arttırdı. Ya benim anneme babama da bir şey olursa korkusu haliyle derslere de yansidr." (Ö11).

"7 olarak puanlayabilirim. Az değil kaygım. Hatta bazen 8 bile oluyor olabilir. Dediğim gibi sürekli etraf ne der korkusu da var içimde. Bunu sebebi biraz da annem babam ama yine de destek alamam gerebilir." (Ö16).

Covid-19 Süreci Sınav Kaygısını Azaltma Önerileri: Araştırmanın nitel bulgularına göre on ikinci sınıf öğrencileri sınav kaygısını azaltmak için; "ders çalışma" (8/16) sürecine önem verilmesinin önemine; öğrencilere yönelik "psikolojik testler ve destek" (4/16) hizmetlerinin olması gerektiğine; "müzik dinleme ve söyleme" (4/16) durumlarının kendilerini rahatlattığına değinmişlerdir. Ayn zamanda "spor yapma" (4/16); "nefes egzersizleri" (3/16); "kitap okuma" (3/16) süreçlerinin kaygılarını azalttı̆̆ına değinen öğrenciler; "online sınavlar" (3/16) ile kaygının giderileceğini düşünmekte; "sokağa çıkma izni" verilmesi (2/16); "rahat ortamlar" (2/16) sağlanması; "sınavların kolaylaştırılması" (2/16) ve "sosyal medya" (2/16) kullanımı ile iyi hissettiklerini ifade etmişlerdir. "Kendine güven" (1/16) duygusunun önemine; "tedbirlerin arttırılması" (1/16) sürecinin gerekliliğine; "ilgili ögretmen" (1/16) ihtiyacının önemine ve "anne baba ilgisi" (1/16) durumuna da dikkat çekilmiştir. Bu tema ile ilgili öğrencilerden bazılarının görüşleri şu şekildedir:

"Normalde spor yapıyordum. Şu an Covid-19 var ve dişarı çıkamıyorum. Ama spor yaparken kaygım azalıyordu, ben çok fayda görmüştüm. Bazen de müzik dinliyorum..." (Ö1).

"Aslında bu konuda daha önceden psikolog desteği aldım. Onun bana öğrettiğ $i$ bazı nefes egzersizleri vardı. Onları uyguluyorum kaygılanınca. Adı sanırım güvenli alandı... (Ö2).

"Sinavlar online olabilirdi, çünkü virüsten korkuyorum ben. Yani bu kadar dikkat ettik sınava gidince bulaşsın istemiyorum..." (Ö3). 
"Sinavlar online olabilir, sorular kolay sorulabilir. Öğrenciler de not korkusu yaşamaz. Bu hep böyle online gidecekse özellikle üniversite sinavina yönelik dersler planlanabilir. Mahallelerde gençlerin spor yapacağı alanlar oluşturulabilir. Ücretsiz spor eğitimi dersleri konabilir: mesela pilates..." (Ö4).

"Online da olsa dersleri ciddiye alıp, dinlerseniz ve programlı çalışırsanız kaygı yaşamazsını tabi. Yani pandemi de sürekli telefon, bilgisayar takılıp, evde boş boş yatan, tüm dizileri bitiren benim gibi insanlar, sinavlar yüz yüze diyince kaygzlanıyor." (Ö5).

"Daha planlı çalışılıp tekrar yapmak kesinlikle kaygıyı azaltır. Psikolojik destek almak gerekebilir." (Ö14).

Psikolojik Sağlamliğın Anlamlandırılması: Araştırmanın nitel bulgularına göre on ikinci sınıf öğrencilerinden psikolojik sağlamlığın anlamlandırılması istendiğinde öğrenciler psikolojik sağlamlığ yoğun bir şekilde "güçlü olma" (12/16) olarak nitelendirmiştir. Aynı zamanda öğrencilerin büyük bir kısmı "mutlu olma" (6/16); "sağlam olma" (6/16); "yılmama" (4/16) olarak anlamlandırırken; bir kısım öğrenci de "iyi olma" (3/16); "üstesinden gelme" (2/16); "toparlayabilme" (2/16); "dik durma" (2/16); "soğukkanlılık" (1/16) ve "takıntılı olmama" (1/16) olarak ifade etmiştir. Bu tema ile ilgili öğrencilerden bazılarının görüşleri şu şekildedir:

"Zor olayların üstesinden gelmek ve güçlü olmak sanırım. Ne olursa olsun mutlu olmak da olabilir. Dik durmak da diyebiliriz..." (Ö1).

"Güçlü olmak, yani ben de olmayan şeyi anlıyorum. Sorunların üstesinden gelmek, küçük şeylere takılmamak, büyütmemek. Dirayetli olmak. Mutlu olmak ama sanal anlamda değil gerçek anlamda mutlu ve güçlü olmak..." (Ö3).

"Güçlü olmak ve iyi bir psikolojiye sahip olmak olabilir. Yani ben psikolojik olarak sağlamlı̆̆ın zaten zor olan hayat şartlarında yılmamak ve hayata tutunup mutlu olmak olduğunu düşünüyorum." (Ö7).

"Güçlü ve sağlam olmak yani psikolojik olarak. Belki içinde bulunduğumuz yaş dönemi gereğince, ergenlik yani fazla duyguyu bir arada yaşayabiliyorum ben. Özellikle özel günlerimde depresif oluyorum mesela..." (Ö9).

"Güçlü ve sağlam bir ruh sağlh̆̆ını anlıyorum tabi ki. Önemli bir kavram. En nihayetinde güçlü psikoloji hepimiz için. Kendi kendine yapabilirim demek ve bunu sık sık tekrarlamak. Bu tabi sinav kaygisından da fazlası sanırım. Hayatın içinde psikolojik olarak sağlam olmak. Bu da tabi her zaman mümkün değil. Hayat herkese eşit davranmıyor, herkes birbirinden farkl..." (Ö10). 
Psikolojik Sağlamlığın Korunması: Araştırmanın nitel bulgularında on ikinci sınıf öğrencilerinin psikolojik sağlamlıklarını korumak adına neler yaptıkları sorusuna verdikleri cevaplar incelendiğinde büyük bir çoğunluğun "spor yapma" (9/16); "müzik dinleme" (7/16); "aile ile vakit geçirme" (6/16); "sosyal medya kullanma" (6/16) ve "yürüyüş" (5/16) faaliyetlerini gerçekleştirdikleri görülmüştür. Yine öğrencilerin psikolojik sağlamlıklarını korumak adına "kitap okuma" (4/16); "dua etme" (4/16); "düzenli uyku" (4/16); "film/dizi izleme" (4/16); "sağllklı beslenme" (3/16); "programlı çalışma" (3/16); "şiir okumalyazma" (3/16); "video izleme" (3/16); "dans etme" (2/16); "sanat" (2/16); ve "ders çalışma" (1/16) faaliyetlerinde bulundukları görülmektedir. Bu tema ile ilgili öğrencilerden bazılarının görüşleri şu şekildedir:

“Ölüm yaşadık, sonra bol bol dua ettim. Duaya sığındım sonuçta. Onlara rahmet ettim. Allah'a başta anne babam olmak üzere sevdiklerimi korumast için bol bol dua ettim. Müzik dinledim, dediğim gibi müzik açıp dans ettim. Annem babam ve kardeşlerimle daha kaliteli vakit geçirdim. Onların değerini anladım. Evde sürekli kapah olmak zor olsa da iyi ve şansh olduğumuz tarafları görmeye çalışarak şükrettim." (Ö11).

"Konu eksiği bırakmamaya çalıştım. Olabildiğince var olan programıma uydum. Kendime güvenmeye devam ettim... Evde az da olsa spor yapmaya çalıştım. Çok fazla uyumaktan kaçındım." (Ö12).

"Sevdiklerimle online görüşmeler yaptım. Sevdiğgim filmleri izledim. Bol bol roman okudum. Evde müzik açıp, dans ettim. İzinler olduğunda çıkıp sahile gidip deniz havası aldım. Çok fazla yememeye çalıştım. Günümü sürekli uyuyarak geçirmekten kaçındım." (Ö13).

"Ailemle daha fazla vakit geçirmeye çalıştım. Konu eksiğimi kapatıp, farklı alanlardan daha fazla soru çözmeye çalıştım. Müzik dinledim. Spor yapmaya çalıştım." (Ö14).

"Kilo almamak için internetten videolar açıp evde mümkün olduğunca spor yapmaya çalıştım. Evde yapmak zor tabi gerçekten. Sürekli kapalı kalmak gerçekten sinir bozucu... Sevdiğim birkaç roman serisi vardı, onları baştan okudum... Bu süreçte yakının kaybeden çok arkadaşım oldu... Zamanım oldukça dua ettim." (Ö15).

Kişisel Psikolojik Sağlamlı̆̆ın Derecelendirilmesi: Araştırmanın nitel bulgularına göre on ikinci sınıf öğrencilerinden Covid-19 süreci psikolojik 
sağlamlık durumları ile ilgili 1 ile 10 arasında bir puanlama yapılması istendiğinde; öğrencilerin yoğun bir şekilde Altı (7/16) ve Yedi (4/16); k1smen de Dört (2/16), Sekiz (2/16) ve Dokuz (1/16) derecelendirmelerini yaptıkları görülmektedir. Öğrencilerin büyük bir bölümü ortalamanın üstünde psikolojik sağlamlık durumu bildirimi yapmıştır. Bu tema ile ilgili öğrencilerden bazılarının görüşleri şu şekildedir:

"Normalde 8 derdim ama babaannemi kaybedince 6'ya düştü. Çok severdim onu. Bir de ne kadar kendimizi ve ruh sağlı̆̆ımızı korumaya çalışsak da zor oluyor bizim için. Anne babamız gibi değiliz yani. Belki de denilen gibi ergenlik dolayısıyla çok da güçlü olamıyoruz." (Ö1).

"Bence 8-9 arası. Hatta 9 diyelim yani sağlam olmayacak bir şey yok. İyiyim gayet. Bence bedenen sağhlkh olmak büyük bir lüks. Buna önem veriyorum. Fiziksel sorun yaşasam ruh sağhlğ̆ıma yansır ama öyle bir durum yok. Evet, sinav için kaygılanıyorum ama sonra dönüp elimden geleni yapıyorum diye kendimi de motive ediyorum." (Ö2).

"5 bile veremem 4 iyidir. Şişman bir kızım yani şu an. Zayıflayana kadar, Covid-19 bitip normal hayata dönene kadar her ne yaparsam yapayım çok fazla yükselmez. Gerçekten daral geldi çünkü bana..." (Ö3).

"6 derdim ama Covid-19 sürecinden dolayı böyle. Cidden bıktım usandım. Artık rahatça bir kafede arkadaşımla buluşup kahve içmek istiyorum. Normalde daha hayat dolu bir insanım ama şu ana yoruldum. Bitsin biran önce bu yasaklar..." (Ö4).

"7 diyebilirim. İstediğim nokta da değilim evet ama bence epey güçlüyüm ben. Sağlamım yani. Psikolojimin bozulduğu noktalarda da kendi bulduğum yöntemlerle düzeltmeye çalışıyorum tabi ki." (Ö7).

"6 derim. Çünkü bu kayıplardan sonra çok düştü. Insanlara belli etmemeye çalışsam da korkularım devam ediyor. Geceleri bazen sıçrayarak ve ağlayarak uyanıyorum. Să̆lamlığım 6'dan fazla olamaz o yüzden." (Ö11).

Covid-19 Sürecinde Psikolojik Sağlamlık Derecesini Arttırma Önerileri: Araştırmanın nitel bulgularına göre on ikinci sınıf öğrencileri psikolojik sağlamlık derecelerini arttırma adına "spor ve hareket" (13/16) egzersizleri yapabileceklerini; "sosyal medyayı kullanmama" (9/16) adına kendilerini motive edebileceklerini; "arkadaşlarla görüşme" (7/16) sürelerini arttırabileceklerini; "düzenli çalışma programı" (5/16) uygulayabileceklerini ve "müzik dinleme ve söyleme" (5/16); "dizi/film izleme" (5/16); "kitap okuma" 
(4/16); "sağlıklı beslenme" (4/16); "uyku düzeni" (3/16); "verimli çalışma" (3/16) hususlarında motive olabileceklerini dile getirmişlerdir. Aynı zamanda "aile ile vakit geçirme" (2/16); "bitki ve çiçek yetiştirme" (2/16); "evcil hayvan bakma" (2/16); "kendine değer verme" (1/16); "hedefler belirleme" (1/16); "dua etme" (1/16) ve "bilgisayar oyunu oynama" (1/16) durumlarının kendilerine iyi gelebileceğine değinmişlerdir. $\mathrm{Bu}$ tema ile ilgili öğrencilerden bazılarının görüşleri şu şekildedir:

"Evlere ücretsiz ilgi çeken kitaplar gönderilip sosyal medyaya uzak kalarak ruh sağhlğ̆ımızı korumamız yani sağlamlaştırmamız sağlanabilir. Çünkü sürekli sosyal medyaya bakmak da ruh sağlığını bozuyor..." (Ö1).

"Az yenebilir, spor yapılabilir, daha çok kitap okunup, daha çok ders çalışılabilir... Özellikle eksikleri kapatmak için ideal bir dönem. Tabi verimli değerlendirebilene. Daha az uyunup, daha az sosyal medyaya bakılabilir..." (Ö3).

"Spor bence en önemlisi. Hem mutluluk hormonu salgilanır hem de kilo almayınca kesinlikle daha iyi hissedersiniz. Sürekli telefona ve bilgisayara bakmak çok kötü. Belki onlardan daha da fazla uzak durulabilir. Arkadaşlarla ya da sevilen aile üyeleriyle online görüşmeler de güzel bence..." (Ö4).

"Daha az uyunabilir. Kesinlikle daha az dizi izlenip daha çok kitap okunabilir. Evcil hayvanınızın olması kesinlikle çok iyi... Kişiyi hayata bağlayıp bence psikolojisini düzeltiyor ve să̆lamlığınızı arttırıyor. Duygusal ve başarılı giden bir ilişki kesinlikle iyi gelir. Müzik dinlemek ve iyi filmler izlemek de diyebiliriz. Bir de ben yapamıyorum ama sosyal medyadan uzak durmak..." (Ö5).

"Sevdiğimiz arkadaşlarımız ve ailemizle daha fazla zaman geçirebiliriz. Bence en güzel katkı sağlayanlardan biri de roman okumak, sevdiğimiz romanları... Böyle bizi şu andaki dertlerden kurtarı hayal dünyasına sürükleyen romanları okumak, oldukça faydal." (Ö7).

"Evcil hayvan beslenebilir ya da bitki bakulabilir. Bunlar adeta terapi gibi. Ben toprakla uğraşmayı seviyorum çünkü. Küçük bir arka balkonumuz var orada biber, soğan filan yetiştirmeye çalışıyorum. Takip ettiğim bilim dergileri var onlar insanı inanılmaz rahatlatıyor mesela onu önerebilirim." (Ö10).

"Bol bol dua edilip, maneviyata sığınılabilir. Insan kendini dinleyip ne istediğinin farkına varabilir. Dinlemek istediği müzikleri, izlemek istediği filmleri izleyebilir. Evde az da olsa dans ederek spor yapabilir. Küçük şeylere çok takılmadan hayatın aslında geçici olduğunu görüp, kıymet bilebilir. Ben mesela bitki yetiştiriyorum. Menekşelerim var. İnsanlar kendilerine psikolojik olarak iyi hissettirmesi için böyle hobiler bulabilir." (Ö11). 


\section{Sonuç ve Tartışma}

$\mathrm{Bu}$ araştırmada Covid-19 salgının başlamasıyla beraber eğitime online olarak devam etmek zorunda kalan lise son sınıf öğrencilerinin sınav kaygısı ve psikolojik sağlamlıklarının ne düzeyde olduğu, cinsiyet ve okul türü değişkenine göre nasıl farklılaştı̆̆ 1 ve öğrencilerin görüşlerinin neler olduğu açımlayıcı sıralı karma desen yöntemi ile incelenmiştir. Elde edilen sonuçlara göre öğrencilerin sınav kaygısı ortalama puanlarının, ölçekten elde edilebilecek ortalamanın üzerinde olduğu, yani öğrencilerin sınav kaygısının bu süreçte yüksek olduğu anlaşılmaktadır. Covid-19 salgını sırasında hemşirelik öğrencileri arasında kaygı ve başa çıkmayı inceleyen bir çalışma da öğrencilerin bu dönemde kaygılarının yükseldiğini göstermiştir (Savitsky vd., 2020). Yine Çin'de yapılan bir çalışmada bu dönemde kaygı ve depresyon seviyelerinde önemli bir artış olduğu görülmüştür (Ran vd., 2020). Ergenlerle yapılan başka çalışmalarda da Covid-19 sürecinde kaygı düzeylerinde çok ciddi bir artış yaşandığ1 görülmüştür (Liang vd., 2020; Zhang vd., 2020). Lise öğrencileriyle yapılan bir çalışmada da son sınıfa yaklaştıkça öğrencilerin kaygısının arttığı görülmüştür (Zhou vd., 2020).

Öğrencilerin psikolojik sağlamlık ortalama puanlarının, ölçekten elde edilebilecek ortalamanın üzerinde olduğu, yani öğrencilerin psikolojik sağlamlıklarının beklenenden yüksek olduğu anlaşılmaktadır. Covid-19 salgını sırasında Yunan ergenler arasındaki psikolojik dayanıklılığın değerlendirildiği bir çalışmada kız öğrencilerin ve erkek öğrencilerin dayanıklılığının ortalamanın üzerinde olduğu görülmüştür (Sakka vd., 2020). Genelde yapılan çalışmalar Covid-19 sürecinde evde karantinada kalan öğrencilerin korku ve kaygılarının arttığını göstermektedir (Cao vd., 2020; Saurabh ve Ranjan, 2020).

Nicel analizler sonucunda kız öğrencilerin Covid-19 sürecinde online eğitim sürecine devam ederken yaşadıkları sınav kaygısının erkek öğrencilerin yaşadı̆̆ı sınav kaygısına göre daha yüksek olduğunu söylenebilir. Covid-19 salgını sırasında Yunan ergenler arasındaki sınav kaygısının değerlendirildiği bir çalışmada kız öğrencilerin sınav kaygısının erkek öğrencilere göre daha yüksek olduğu görülmüştür (Sakka vd., 2020). Yine Covid-19 sürecinde lise öğrencileriyle yapılan bir çalışmada kız öğrencilerin kaygılarının erkek öğrencilere göre daha 
yüksek olduğu görülmüştür (Zhou vd., 2020) Covid-19 sürecinde yapılan bir başka çalışmada kız öğrencilerin kaygılarının erkek öğrencilere göre daha yüksek olduğu görülmüştür (Savitsky vd., 2020). Yapılan analiz sonucunda psikolojik sağlamlık puan ortalamalarına göre kız öğrencilerin puan ortalamalarının erkek öğrencilerden istatistiksel olarak anlamlı düzeyde farklı olmadığı saptanmıştır. Covid-19 salgını sırasında Yunan ergenler arasındaki psikolojik dayanıklılığın değerlendirildiği bir çalışmada kız öğrencilerin ve erkek öğrencilerin dayanıklılığının arasında anlamlı bir fark olmadığı görülmüştür (Sakka vd., 2020). Nicel analizler sonucunda sınav kaygısı puanlarının okul türü (Anadolu lisesi, Fen lisesi ve Meslek lisesi) değişkenine göre istatistiksel olarak anlamlı derecede farklılaşmadığ1 görülmüştür. Psikolojik sağlamlığın okul türüne göre farklılaştı̆̆1 ve Fen lisesindeki öğrencilerin psikolojik sağlamlıklarının Anadolu lisesindeki öğrencilere göre daha yüksektir. Meslek lisesindeki öğrencilerin psikolojik sağlamlıkları Anadolu lisesindeki öğrencilere göre daha yüksektir.

Araştırmanın nitel verilerinin analizi sonucunda 8 (sekiz) araştırma sorusuna bağlı olarak, toplamda 99 kod ortaya çıkmış ve bu kodlardan 8 (sekiz) tema oluşturulmuştur. Bu temalar; "sınav kaygısı ve sonuçları", "Covid-19 süreci eğitim sistemi ve kaygılar", "ortalamanın üstünde kayg1 durumu”, ,Covid-19 süreci sınav kaygısını azaltma önerileri", "psikolojik sağlamlığın anlamlandırılması", "psikolojik sağlamlığın korunması", "kişisel psikolojik sağlamlığın derecelendirilmesi" ve "Covid-19 sürecinde psikolojik sağlamlık derecesini arttırma önerileri" olarak sunulmuştur.

Covid-19 pandemisi ayn zaman zarfında birden fazla bireyin normal yaşantısını negative yönde etkilediği ve çok sayıda belirsizlik durumu barındırdığından dolayı kaygıya sebebiyet vermektedir. Virüsün yayılma süreci ve insanlar arasında bulaşma hızı kişisel ilişkilere de baskı kurmaktadır. Salgı sürecinin ne kadar devam edeceği ve kötüye gidip gitmeyeceği hakkında yeteri kadar bilgi olmadığından dolayı ortaya çıkan belirsizlik durumları kaygı yaratmaktadır (Çicek ve Almalı, 2020). Araştırmanın bulgularında öğrencilerin yaşadıkları sınav kaygıları ve bu kaygıların kendilerinde yarattığı sonuçlar ile ilgili değerlendirmeleri önemlidir. Araştırma kapsamındaki 12. son sınıf öğrencileri yaşadıkları sınav kaygılarını; başaramama korkusu, heyecanlanma, fiziksel çöküntü 
içerisinde olma olarak adlandırmışlardır. Herhangi bir pandemi sürecinin medyada uzun bir süre yer alması normal olarak korkuların oluşmasına ve kaygıların yaşanmasına sebebiyet verebilir (Wheaton vd., 2011).

Araştırma bulgularına göre 12. son sınıf öğrencileri; Covid-19 sürecindeki eğitim sisteminde kaygılarının daha da arttığını, derslerine konsantre olmakta güçlük çektiklerini, online eğitim sisteminin ve sinavların başarısız olduğunu ve yüz yüze eğitimin daha kaliteli olduğunu dile getirmişlerdir. Kurtuncu ve Kurt (2020) araştırmasında; öğrencilerin birçoğunun uzaktan eğitim ile gerçekleştirilecek sınavlara güvenmediklerini ve düşük notlar alarak derslerinden kalma riski ile karşılaşabileceklerini belirtmiştir. Yine farklı bir araştırmada Covid-19 sürecinde kapatılan eğitim kurumlarının öğrencilerin çektikleri sıkıntılardan bazılarının; "yüz yüze gerçekleşen derslerden online derslere geçiş", "sınavların süreçlerinin nasıl gerçekleştirileceği", ve "sağlık" olduğu aktarılmıştır (Sahu, 2020). Genç ve Gümrükçüoğlu'nun (2020) araştırma sonuçlarına bakıldığında Covid-19 süreci ile başlayan uzaktan eğitim sisteminde okuyan öğrencilerin memnuniyet seviyesi $\% 23,1$ oranındadır. Yine bu araştırma sonuçları incelendiğinde online eğitimden verim alan öğrenci oranı \%15,3, derslere konsantre olabilenlerin oranı $\% 17,8$, sinavlara konsantre olabilenlerin oran $\% 23,9$, derslere verimli bir şekilde çalışabilenlerin oranı $\% 14,8$ ve derslerden yüz yüze eğitimlerdeki gibi verim alındığını belirtenlerin sayısı ise \%15,3'dür. Bu sonuçlar araştırmanın sonuçları ile bağdaşmaktadır.

Pandemi sürecinin sebebiyet verdiği olumsuz etki durumları dikkate alınarak okullardaki ve uzaktan eğitimdeki eğitim-öğretim yöntemlerinin değişmesi, her öğrencinin tek ve biricik olması göz önüne alınarak, okul çalışmalarının dönüştürülmesi ve her bir öğrenciyi kapsam içerisine almaya çalışması gerçekleştirilmelidir. Bu sürecin ne zaman normale döneceği ile ilgili belirsiz durumları kaygıyı arttırmaktadır. Eğitim kurumları eğitim öğretim faaliyetleri için gerekli değişimleri gerçekleştirseler de aktif iletişim zinciri sağlanarak, öğrenci ve velilere güven duygusunun aşlanmasına önem verilmelidir (Kara, 2020). Araştırma sonuçlarına göre öğrencilerin özellikle Covid-19 sürecinde kayg1 durumlarının arttığı görülmekte ve bu durum kendileri tarafından da ifade edilmektedir. Öğrencilerin kendilerine kaygı durumlarının 
seviyesi sorulduğunda büyük bir çoğunluğu ortalamanın üstünde geribildirim verdikleri görülmektedir.

Kişilerin kaygılarından uzaklaşarak psikolojik anlamda sağlam kalmaları hem onları riskli durumlardan koruyacak hem de travmalar ve buna benzer durumların yaşanmamasını ya da yaşansa bile onları aşmasını kolaylaştıracaktır (Richardson, 2002). Araştırma bulgularına göre Covid-19 sürecinde 12. son sınıf öğrencilerinin sınav kaygılarını azaltmak için düzenli ders çalıştıkları fakat bununla beraber psikolojik desteğe ihtiyaç duydukları; müzik dinleme, spor yapma, kitap okuma ve nefes egzersizi gibi faaliyetlerde bulundukları ifade edilmiştir. Sever ve Özdemir (2020), araştırmalarında kaygı durumlarında ders ve sınavları uzaktan eğitim vasıtası ile tamamlamanın hem öğrenciler için hem de akademisyen adına farklı bir deneyim oluşturduğunu dile getirmişlerdir. Aynı araştırmanın katılımcılarından bazıları bu deneyimde: "yatakların yüz yüze eğitimdeki sınıf sırasını, bilgisayarların ise yüz yüze eğitimdeki kalem ve defteri", temsil ettiğini ifade etmiş; başka bir katılımcı da "Pandemi sürecinde 'öğrenci olmayı' Titanik filminde yer alan dev gemi batarken keman çalan müzisyenler gibi olmaya" benzetmiştir.

Ramirez (2007) psikolojik sağlamlığı; hastalıktan, olumsuz süreçlerden, depresif duygular ve benzeri olayların sonunda kolayca toparlanabilme, zor yaşam süreçlerinden sonra eskisi gibi olabilme şeklinde tanımlamıştır. Araştırmanın bulgularına göre son sınıf öğrencileri de psikolojik sağlamlığı; güçlü olma, mutlu olma, sağlam olma, yılmama ve iyi görünme olarak anlamlandırmışlardır. Psikolojik sağlamlığı kısaca ifade edecek olursak; olumsuz durumların ertesinde bireylerin ortaya koyduğu başa çıabilme ve uyum becerisi şeklinde ifade edilebilir (Block ve Kremen, 1996).

Araştırmanın bulgularında on ikinci son sınıf öğrencileri psikolojik sağlamlığın korunması için; spor yapılabileceğini, müzik dinlenebileceğini, aile ile vakit geçirilebileceğini, yürüyüş yapılabileceğini ve kitap okunabileceğini ifade etmişlerdir. Çelebi (2020), araştırmasının önerilerinde vatandaşların Covid-19 sürecinde kaygılarıyla başa çıkabilmeleri ve psikolojik sağlamlıklarını korumaları adına sunduğu önerilerden bazıları şunlardır: 
- Uzun süre pandemi ile ilgili yayınlar izlemekten sakınmak,

- Bilgiyi güvenilir kaynaklardan almak,

- Olumlu düşünme, riskli durumları kabullenme fakat önlemler almak, motivasyonu yüksek tutmak,

- Kaygının normal bir süreç olduğunu kabullenme ve baş etmek için çaba sarf etmek,

- Evde keyif veren (spor, egzersiz, puzzle, bilgisayar oyunları) gibi etkinlikler yapmak,

- Mizah yükseltici ve iyi gelen filmler izlemek,

- Nefes egzersizleri yapmak.

Psikolojik sağlamlık, en geniş tanımı ile bireylerin sıkıntılara dayanma yetenekleri olarak tanımlanır (Jackson vd., 2007). Aynı zamanda psikolojik sağlamlık, karşılaşılan travmatik ve riskli durumlara rağmen bireylerin sağlıklı bir biçimde bu sürece uyum sağlamasını gerçekleştiren bir terimdir (Masten ve Gewirtz, 2006). Araştırmanın bulgularında kişisel psikolojik sağlamlık durumlarını değerlendiren öğrencilerin büyük bir çoğunluğu ortalamanın üzerinde bir sağlamlık düzeyine sahip olduğunu fakat Covid-19 sürecinden dolayı bu sağlamlık düzeyinde belirgin bir düşüş yaşadıklarını dile getirmişlerdir. Psikolojik sağlamlık sayesinde birçok insanın karşılaştığı zorluklar ile mücadele etmesiyle daha güçlü hale geldiğine dair olumlu görüşlerin olduğu aktarılmaktadır (Polizzi vd., 2020).

\section{Öneriler}

Covid-19 sürecinde eğitimlerine online olarak devam eden on ikinci sinıf öğrencilerinin sınav süreçlerinde yaşadıkları kaygı durumları ve psikolojik sağlamlıklarının düzene sokulması adına araştırmacılar tarafından aşağıdaki öneriler sunulmuştur:

- Kaygı düzeyi yüksek olan öğrenciler için profesyonel psikolojik destekler sağlanabilir.

- Sınav kaygısı yaşayan öğrencilerin kaygısını azaltacak online eğitimler düzenlenebilir.

- Sikça problem yaşandığı dile getirilen online eğitim sisteminin iyileştirilmesi ve yüz yüze eğitim seviyesine ulaştırılması için çalışmalar hızlandırılabilir. 
- Evde kalan öğrenciler için sosyal etkinlik projesi olarak online spor etkinlikleri düzenlenebilir.

- Öğrencilerin rahatlaması ve kendini iyi hissetmeleri adına ücretsiz müzik dinleme ve kitap okuma ve şiir dinleme programları oluşturulabilir.

- Öğrencilerin fiziksel çöküntü içerisine girmemeleri için, günün ve haftanın belirli günlerinde okullarda öğretmen, arkadaş ve sosyal destek uzmanları ile bir araya gelmeleri sağlanabilir. 


\section{EXTENDED ABSTRACT}

\section{Examination of Exam Anxiety and Psychological Resilience of Students Continuing Education in Covid-19 Process with Mixed Methodology \\ İsmail Erol-Özge Erduran Tekin \\ Namık Kemal University- National Defense University}

\section{Introduction and Problem Statement}

Adolescents, unlike adults, have not usually grown in psychological maturity to manage challenging situations. Therefore, it is much more difficult for adolescents to protect their mental health than adults in difficult times, which is a global threat such as a pandemic, which obliges intensive and long-term measures to be taken (Fegert et al., 2020; Xiang et al., 2020; Crone \& Dahi, 2012; Roy et al., 2020). The bans placed in the term of pandemic had various psychological repercussions and led to an increase in the anxiety of senior high school students who were preparing for an exam that would determine their lives, such as the university exam (Abuhammad et al., 2020; Kim, 2020). This situation experienced by the adolescents who continue online education and stay at home longer than expected has led to academic difficulties and an increase in exam anxiety, which is one of the anxiety types (Alfoukha et al., 2019; Liang et al., 2020). It is thought that determining and improving the psychological resilience of high school students who continue their education online during the Covid-19 process (Joyce et al., 2018) will enable students to cope with these processes, positively affect the reduction of their anxiety, and even increase their academic success (Robertson et al., 2015) . For this purpose, the main purpose of the study was to examine the exam anxiety and psychological resilience of senior high school students, who had to continue their education online in various districts of 
Istanbul with the onset of the Covid-19 pandemic by using the explanatory sequential mixed design method.

\section{Method}

The aim of the study is to examine the level of exam anxiety and psychological resilience of high school seniors who had to continue their education online with the onset of the Covid-19 pandemic, how they differ according to gender and school type variable, and the views of the students through the explanatory sequential mixed design method. While the universe of the research consisted of $12^{\text {th }}$ grade students in Turkey, the sample was composed of 401 students who continued their education online in the 2021 academic year and were selected by the convenient sampling method, which is one of the nonrandom sampling methods. For the qualitative dimension of the study, 16 participants were determined by using the maximum diversity sampling method, which is included in the purposeful sampling method from the students participating in the quantitative aspect of the study. The feature determined here is the type of school, gender, high or low exam anxiety and high or low psychological resilience in order to obtain in-depth information. Westside Test Anxiety Scale, Psychological Resilience Scale for Children and Adolescents, Personal Information Form and Semi-Structured Interview Form were used in the study. A semi-structured interview form prepared by the researchers was used in the qualitative dimension. Data were collected in April 2021. The "content analysis" method was preferred in the analysis process of qualitative data.

\section{Findings}

It was observed that the exam anxiety and psychological resilience scores of the students participating in the study were above the average. It was determined that the mean scores of the female students were statistically significantly higher than the mean scores of the male 
students compared to the test anxiety mean scores as a result of the analysis $(p<0.01)$. While it was observed that exam anxiety scores did not differ statistically significantly according to the school type variable (Anatolian high school, Science high school and Vocational high school) $\left[\mathrm{F}_{(2-398)}=.111, \mathrm{p}>0.05\right]$, psychological resilience scores differed statistically significantly according to the school type variable (Anatolian high school, science high school and vocational high school) $\left[\mathrm{F}_{(2-398)}=3.917, \mathrm{p}<0.05\right]$. Psychological resilience of students in science high school is higher than students attending Anatolian high school. The psychological resilience of the students in vocational high schools is higher than the students in Anatolian high school. As a result of the analysis of the qualitative data obtained through structured interviews, a total of 99 codes emerged depending on 8 (eight) research questions and 8 (eight) themes were formed from these codes. These themes have been presented as "exam anxiety and its results", "Covid-19 process education system and concerns", "above-average anxiety", "recommendations to reduce Covid19 process exam anxiety", "meaningful of psychological resilience", "protection of psychological resilience", "grading of personal resilience" and "Suggestions to increase the degree of resilience in the Covid-19 process".

\section{Discussion and Suggestions}

According to the results obtained, it is understood that the exam anxiety and psychological resilience of the students are high in this process. As a result of the quantitative analysis, it can be said that the exam anxiety experienced by female students while continuing the online education process during the Covid-19 period is higher than the exam anxiety experienced by male students. As a result of the analysis, it was determined that the mean scores of female students according to the mean scores of psychological resilience were not statistically different from those of male students. The $12^{\text {th }}$ senior students within the scope of the research named their exam anxiety as fear of failing, getting excited, and being in a physical depression. According to the research findings, $12^{\text {th }}$ senior students stated that their level of anxiety increased in the education system during the Covid-19 period, they had difficulty concentrating on 
their lessons, the online education system and exams were unsuccessful, and the face-to-face education was higher quality. According to the findings of the research, it has been stated that the $12^{\text {th }}$ senior students study regularly to reduce their exam anxiety, but they also need psychological support, they engage in activities such as listening to music, doing sports, reading books and breathing exercises. The following suggestions were made by the researchers in order to regulate the anxiety and psychological resilience of the twelfth grade students who continue their education online during the Covid-19 process:

- Professional psychological support can be provided for students with high levels of anxiety.

- Online trainings can be organized to reduce the anxiety of students with exam anxiety.

- Studies can be accelerated to improve the online education system, which is said to be a frequent problem, and to bring it to the level of face-to-face education.

- Online sports events can be organized as a social activity project for students staying at home.

- Free music listening, reading books and poetry listening programs can be created for students to relax and feel good.

- It can be ensured that students come together with teachers, friends and social support specialists at schools on certain days of the day and week so that they do not go into physical depression. 


\section{Kaynakça / References}

Abuhammad, S., Khabour, O. F. ve Alzoubi, K. H. (2020). COVID-19 contacttracing technology: Acceptability and ethical issues of use. Patient Preference and Adherence, 14, 163.

AlAzzam, M., Suliman, M. ve ALBashtawy, M. (2017). School nurses' role in helping children with attention-deficit/hyperactivity disorders. NASN School Nurse, 32(1), 36-38.

Alfoukha, M. M., Hamdan-Mansour, A. M. ve Banihani, M. A. (2019). Social and psychological factors related to risk of eating disorders among high school girls. The Journal of School Nursing, 35(3), 169177.

Al-Rabiaah, A., Temsah, M. H., Al-Eyadhy, A. A., Hasan, G. M., Al-Zamil, F., Al-Subaie, S., ...Somily, A. M. (2020). Middle East Respiratory Syndrome-Corona Virus (MERS-CoV) associated stress among medical students at a university teaching hospital in Saudi Arabia. Journal of Infection and Public Health, 13(5), 687-691.

Arslan, G. (2015). Çocuk ve Genç Psikolojik Sağlamlık Ölçeği'nin (ÇGPSÖ-12) psikometrik özellikleri: Geçerlilik ve güvenirlik çalışması. Ege Eğitim Dergisi, 16(1), 1-12.

Bahmani, D. S., Hatzinger, M., Gerber, M., Lemola, S., Clough, P. J., Perren, S., ...Brand, S. (2016). The origins of mental toughness-Prosocial behavior and low internalizing and externalizing problems at age 5 predict higher mental toughness scores at age 14. Frontiers in Psychology, 7. https://doi.org/10.3389/fpsyg.2016.01221.

Baloran, E. T. (2020). Knowledge, attitudes, anxiety, and coping strategies of students during Covid-19 pandemic. Journal of Loss and Trauma, 25(8), 635-642. https://doi.org/ 10.1080/15325024.2020.1769300.

Bethell, C. D., Newacheck, P., Hawes, E. ve Halfon, N. (2014). Adverse childhood experiences: Assessing the impact on health and school engagement and the mitigating role of resilience. Health Affairs, 33(12), 2106-2115.

Block, J. ve Kremen, A. M. (1996). IQ and ego resiliency: Conceptual and empirical connections and separateness. Journal of Personality and Social Psychology, 70(2), 349-361.

Brooks, B. D., Alshafei, D. ve Taylor, L. A. (2015). Development of the test and examination anxiety measure (TEAM). Psi Chi Journal of Psychological Research, 20(1), 2-10. 
Brooks, S. K., Webster, R. K., Smith, L. E., Woodland, L., Wessely, S., Greenberg, N. ve Rubin, G. J. (2020). The psychological impact of quarantine and how to reduce it: Rapid review of the evidence. The Lancet, 395(10227), 912-920.

Buz, S. ve Genç, B. (2019). Sosyal hizmet uzmanları için psikolojik dayanıklılığın önemi. Toplum ve Sosyal Hizmet, 30(2), 623-642.

Büyüköztürk, Ş., Çakmak, E. K., Akgün, Ö. E., Karadeniz, Ş. ve Demirel, F. (2014). Bilimsel araştırma yöntemleri. Ankara: Pegem Akademi.

Cao, W., Fang, Z., Hou, G., Han, M., Xu, X., Dong, J. ve Zheng, J. (2020). The psychological impact of the Covid-19 epidemic on college community mental health journal 13 students in China. Psychiatry Research, 287, 112934. https://doi.org/10.1016/jpsychres. 2020.112934.

Chen, Q., Liang, M., Li, Y., Guo, J., Fei, D., Wang, L., ...Zhang, Z. (2020). Mental health care for medical staff in China during the COVID-19 outbreak. Lancet Psychiatry, 7, 15-16.

Creswell, J. W. ve Plano Clark, V. L. (2015). Karma yöntem araştırmaları tasarımı ve yürütülmesi (Y. Dede ve S. B. Demir, Çev. Ed.). Ankara: Anı Yayıncilik.

Crone, E. A. ve Dahl, R. E. (2012). Understanding adolescence as a period of social-affective engagement and goal flexibility. Nature Reviews Neuroscience, 13(9), 350-636.

Çelebi, G. Y. (2020). Covid 19 Salgınına ilişkin tepkilerin psikolojik sağlamlık açısından incelenmesi. IBAD Sosyal Bilimler Dergisi, 8, 471-483.

Çiçek, B. ve Almalı, V. (2020). Covid-19 pandemisi sürecinde kaygı özyeterlilik ve psikolojik iyi oluş arasındaki ilişki: Özel sektör ve kamu çalışanları karşılaştırması. Turkish Studies, 15(4), 241-260.

Duan, L. ve Zhu, G. (2020). Psychological interventions for people affected by the Covid-19 epidemic. Lancet Psychiatry, 7, 300-302.

Fegert, J., Vitiello, B., Plener, P. ve Clemens, V. (2020). Challenges and burden of the Coronavirus 2019 (Covid-19) pandemic for child and adolescent mental health: A narrative review to highlight clinical and research needs in the acute phase and the long return to normality. Child and Adolescent Psychiatry and Mental Health, 14, 20.

Field, A. (2009). Discovering statistics using SPSS (Third Edition). London: SAGE Press. 
Genç, M. F. ve Gümrükçüoğlu, S. (2020). Koronavirüs (Covid-19) sürecinde ilâhiyat fakültesi öğrencilerinin uzaktan eğitime bakışları. Turkish Studies, 15(4), 403-422.

Gibson, H. (2014). A conceptual view of test anxiety. Nursing Forum, 49(4), 267-277.

Guessoum, S. B., Lachal, J., Radjack, R., Carretier, E., Minassian, S., Benoit, L. ve Moro, M. R. (2020). Adolescent psychiatric disorders during the Covid-19 pandemic and lockdown. Psychiatry Research, 291, 113-264.

Jackson D., Firtko A. ve Edenborough M. (2007) Personal resilience as a strategy for surviving and thriving in the face of workplace adversity: A literature review. Journal of Advanced Nursing, 60(1), 1-9.

Joyce, S., Shand, F., Tighe, J., Laurent, S. J., Bryant, R. A. ve Harvey, S. B. (2018). Road to resilience: A systematic review and meta-analysis of resilience training programmes and interventions. BMJ Open, 8(6), Article e017858.

Kara, Y. (2020). Pandemi sürecindeki öğrenci deneyimleri: Bakırköy ilçesi örneği. Avrasya Sosyal ve Ekonomi Araştırmaları Dergisi, 7(7), 165-176.

Kim, K. H. (2020). Covid-19. International Neurology Journal, 24(1), 1-11.

Kurtuncu, M. ve Kurt, A. (2020). Covid-19 pandemisi döneminde hemşirelik öğrencilerinin uzaktan eğitim konusunda yaşadıkları sorunlar. Avrasya Sosyal ve Ekonomi Araştırmaları Dergisi, 7(5), 66-77.

Liang, L., Ren, H., Cao, R., Hu, Y., Qin, Z., Li, C. ve Mei, S. (2020). The effect of Covid-19 on youth mental health. Psychiatric Quarterly, 91(3), 841852. https://doi.org/10.1007/s11126-020-09744-3.

Liebenberg, L., Ungar, M. ve LeBlanc, J. C. (2013). The CYRM-12: A brief measure of resilience. Canadian Journal of Public Health, 104(2), 131-135.

Liu, S., Yang, L., Zhang, C., Xiang, Y.T., Liu, Z., Hu, S. ve Zhang, B. (2020). Online mental health services in China during the COVID-19 outbreak. Lancet Psychiatry, 7, 17-18.

Luthar, S. S., Cicchetti, D. ve Becker, B. (2000). The construct of resilience: A critical evaluation and guidelines for future work. Child Development, 71(3), 543-562.

Masten, A. S. ve Gewirtz, A. H. (2006). Resilience in development: The importance of early childhood. İçinde R. E. Tremblay, R. G. Barr ve R. D. Peters (Edl.), Encyclopedia of early childhood development (p.1-6) http://www.childencyclopedia.com/Pages/PDF/MastenGewirtzANGxp.pdf. 
Metin, M. (2014). Kuramdan uygulamaya eğitimde bilimsel araştırma yöntemleri. Ankara: Pegem Akademi Yayınları.

Norris, F., Tracy, M. ve Galea, S. (2009). Looking for resilience: Understanding the longitudinal trajectories of responses to stress. Social Science Medicine, 68, 2190-2198.

Polizzi, C., Lynn, S. J. ve Perry, A. (2020). Stress and coping in the time of Covid-19: Pathways to resilience and recovery. Clinical Neuropsychiatry, 17(2), 59-62. https://doi.org/10.36131/CN20200204

Ramirez, E. R. (2007). Resilience: A new concept analysis. Nursing Forum, 42(2), 73- 82.

Ran, L., Wang, W., Ai, M., Kong, Y., Chen, J. ve Kuang, L. (2020). Psychological resilience, depression, anxiety, and somatisation symptoms in response to Covid-19: A study of the general population in China at the peak of its epidemic. Social Science $\mathcal{E} \quad$ Medicine, 113261. https://doi.org/10.1016/j.socscimed.2020.113261.

Richardson, G. E. (2002). The metatheory of resilience and resiliency. Journal of Clinical Psychology, 58(3), 307-321.

Robertson, I. T., Cooper, C. L., Sarkar, M. ve Curran, T. (2015). Resilience training in the workplace from 2003 to 2014: A systematic review. Journal of Occupational and Organizational Psychology, 88(3), 533-562.

Roy, D., Tripathy, S., Kar, S., Sharma, N., Verma, S. ve Kaushal, V. (2020). Study of knowledge, attitude, anxiety \& perceived mental healthcare need in Indian population during COVID-19 Pandemic. Asian Journal of Psychiatry, 51, 102083-102087.

Sahu, P. (2020). Closure of universities due to coronavirus disease 2019 (Covid-19): Impact on education and mental health of students and academic staff. Cureus, 2019(4), 4-9.

Sakka, S., Nikopoulou, V. A., Bonti, E., Tatsiopoulou, P., Karamouzi, P., Giazkoulidou, A. ve Diakogiannis, I. (2020). Assessing test anxiety and resilience among Greek adolescents during Covid-19 pandemic. Journal of Mind and Medical Sciences, 7(2), 173-178.

Saurabh, K. ve Ranjan, S. (2020). Compliance and Psychological Impact of Quarantine in Children and Adolescents due to Covid-19 Pandemic. The Indian Journal of Pediatrics, 87(7), 532-536. https://doi.org/ 10.1007/s12098-020-03347-3. 
Savitsky, B., Findling, Y., Ereli, A. ve Hendel, T. (2020). Anxiety and coping strategies among nursing students during the covid-19 pandemic. $\begin{array}{lll}\text { Nurse Education in } & 02809 .\end{array}$ https://doi.org/10.1016/j.nepr.2020.102809.

Sever, M. ve Özdemir, S. (2020). Koronavirüs (Covid-19) sürecinde öğrenci olma deneyimi: Bir fotoses (photovoice) çalışması. Toplum ve Sosyal Hizmet, 31(4), 1653-1679.

Sheerin, C. M., Lind, M. J., Brown, E.A., Gardner, C. O., Kendler, K. S. ve Amstadter, A. B. (2018). The impact of resilience and subsequent stressful life events on MDD and GAD. Depress. Anxiety, 35, 140-147.

Talidong, K. J. B. ve Toquero, C. M. D. (2020). Philippine teachers' practices to deal with anxiety amid Covid-19. Journal of Loss and Trauma. Advance online publication., 25(6-7), 573-579. https://doi.org/10.1080/15325024.2020.1759225.

Totan, T. (2018). Ortaokul ve lise öğrencilerinde sınav kaygısının değerlendirilmesi: Westside sınav kaygısı ölçeği. Batı Anadolu Eğitim Bilimleri Dergisi, 9(2), 143-155.

Totan, T. ve Yavuz, Y. (2009). Westside Sınav Kaygısı Ölçeğinin Türkçe formunun geçerlik ve güvenirlik çalışması. Mehmet Akif Ersoy Üniversitesi Ĕ̆itim Fakültesi Dergisi, 9(17), 95-109.

Wheaton, M. G., Abramowitz, J. S., Berman, N. C., Fabricant, L. E. ve Olatunji, B. O. (2011). Psychological predictors of anxiety in response to the H1N1 (swine flu) pandemic. Cognitive Therapy and Research, 36(3), 210-218.

World Health Organization. (2020). Mental health and psychosocial considerations during the COVID-19 outbreak https://www.who.int/docs/default-source/coronaviruse/mental-healthconsiderations.pdf 01.05.2021 tarihinde erişim sağlanmıştır.

Xiang, Y. T., Yang, Y., Li, W., Zhang, L., Zhang, Q., Cheung, T. ve Ng, C. H. (2020). Timely mental health care for the 2019 novel coronavirus outbreak is urgently needed. Lancet Psychiatry, 7, 228-229.

Yıldırım, A. ve Şimşek, H. (2019). Sosyal bilimlerde nitel araştırma yöntemleri (11. Bask1). Ankara: Seçkin Yayıncılık.

Zhang, C., Ye, M., Fu, Y., Yang, M., Luo, F., Yuan, J. ve Tao, Q. (2020). The Psychological Impact of the COVID-19 Pandemic on Teenagers in China. Journal of Adolescent Health, 67(6), 747-755. https://doi.org/ 10.1016/j.jadohealth.2020.08.026. 
Zhou, S.-J., Zhang, L.-G., Wang, L.-L., Guo, Z.-C., Wang, J.-Q., Chen, J. C., ...Chen, J.X. (2020). Prevalence and socio-demographic correlates of psychological health problems in Chinese adolescents during the outbreak of Covid-19. European Child and Adolescent Psychiatry, 29, 749-758.

\section{Kaynakça Bilgisi / Citation Information}

Erol, İ. ve Erduran Tekin, Ö. (2021). Covid-19 sürecinde eğitime devam eden öğrencilerin sınav kaygısı ve psikolojik sağlamlıklarının karma metodoloji ile incelenmesi. OPUS-Uluslararası Toplum Araştırmaları Dergisi, 18(44), 7818-7854. DOI: 10.26466/opus.936008. 